\title{
The Mu'alamah Dropshipping System: Islamic Economic Perspective
}

\author{
Hendri Hermawan Adinugraha \\ State Islamic Institute of Pekalongan \\ hendri.hermawan@iaimpekalongan.ac.id
}

\author{
Mukhtarom \\ State Islamic Institute of Pekalongan \\ paieksyar@gmail.com
}

Ali Muhtarom

State Islamic Institute of Pekalongan

ali.mubtarom@iainpekalongan.ac.id

\begin{abstract}
This research aims to explain the mu'alamah dropshipping system from an Islamic economic perspective. This study uses a literature or library research method which is sourced from authoritative data and sources, such as books and journals that are still relevant to the focus and discussion of this research. The results of the study concluded that allowing transactions that continue to develop in progress in the economy as long as they do not violate and do not contradict Islamic principles, dropshipping transactions which have now become a custom in society are allowed as long as the perpetrator understands the procedures for transactions, because the system is vulnerable and leads to the cancellation of a contract, namely selling goods that do not belong to him, and the development of technology greatly influenced the development of legal edicts that urged them to be issued. However, on many sides, with the legal norms that have been summarized by previous scholars by looking at the equality of legal illat, it can be found that fast and precise legal answers can be found to determine the law in every legal event for which there is no clear legal provision in al- Qur'an and as-Sunnah.
\end{abstract}

Keywords: Mu'amalah, Dropshipping, Sharia, Islamic Economics.

Abstrak. Penelitian ini bertujuan untuk menjelaskan sistem mu'alamah dropshipping ditinjau dari perspektif ekonomi Islam. Penelitian ini meenggunakan metode kajian pustaka yang bersumber dari data-data dan sumber-sumber otoritatif, seperti buku dan jurnal yang masih relevan dengan fokus serta bahasan penelitian ini. Hasil penelitian menyimpulkan bahwa diperbolehkannya transaksi yang terus berkembang pada kemajuan dalam ekonomi selama itu tidak melanggar dan tidak bertentangan dengan prinsip Islam, transaksi dropshipping yang sekarang telah menjadi kebiasan di masyarakat diperbolehkan selama pelaku mengerti tata cara dalam bertransaksi, karena dalam sistem tersebut rawan dan mengarah pada batalnya suatu akad, yaitu menjual barang yang bukan miliknya, dan perkembangan teknologi banyak mempengaruhi perkembangan fatwa hukum yang mendesak untuk dikeluarkan. Akan tetapi, pada banyak sisi, dengan kaidahkaidah hukum yang telah dirangkum oleh para ulama terdahulu dengan melihat pada kesamaan illat hukum dapat diketemukan jawaban hukum yang cepat dan tepat untuk menetapkan hukum pada setiap peristiwa hukum yang belum ada ketentuan hukum yang jelas dalam al-Qur'an dan as-Sunnah.

Kata kunci: Mu'amalah, Dropshipping, Syariah, Ekonomi Islam. 


\section{INTRODUCTION}

Human life today is inseparable from buying and selling activities, both local and domestic as well as international, humans understand trading practices using various methods and developing models according to the conditions of the times (Putra, 2019). Initially, buying and selling was limited to meeting sellers and buyers directly with the means of transaction and products being traded (Rahmayanti et al., 2020).

This kind of buying and selling process is quite effective and satisfying for both the seller and the buyer, both of them can directly transact and see merchandise to be assessed directly (Fitria, 2017b). The exchange of goods and services can also occur immediately, but this trading model is conventional and very limited in penetrating a wider and more flexible scope of time and place.

Now in the era of globalization, there is a very rapid development of information media, which has contributed to the order of the world economy, say since the advent of the internet and used by the wider community, trading activities have not been spared the use of this technology (Wibowo, 2016; Aco \& Endang, 2017). The internet has become a new activity space for people in the online world, many mu'amalah activities have shifted through internet media, including buying and selling (Maryati \& Masriani, 2019).

Since the advent of the internet, followed by the development of telecommunications devices in the form of smartphones or smart phones based on iOS and Android, a new world has emerged, namely the virtual world (Damayanti \& Gemiharto, 2019). The virtual world makes it easy for everyone to connect with each other around the world while also transcending time and space.

Humans began to develop transactions through the internet network. Various online buying and selling sites have started to emerge, both those owned individually and by market place companies, such as Bukalapak, Lazada, Tokopedia and Shopee (Rismana, 2018; Febriani et al., 2020). This is a step for traders to reach a wider range of potential consumers effectively and efficiently so as to gain more profits. The emergence of social media such as Facebook and Instagram did not escape the targets of traders as new locations for buying and selling online (Kurniawan \& Kosasih, 2020).

Buying and selling online uses several systems, sometimes merchants sell personal merchandise to potential customers, resulting in two-party online transactions without intermediaries. However, there is also buying and selling with the dropship model and the perpetrator is called a dropshiper, where the seller actually does not own the item but only sells other people's items online and the goods will be sent to the buyer or buyer using on behalf of the seller or dropshiper (Imanudi, 2019).

Dropshipping is buying and selling where the reseller or retailer does not have stock of goods (Pitriani \& Purnama, 2020). The producer or wholesaler as the dropshipper who will send the goods directly to the customer. Profits are made from the difference in price between wholesale and retail prices. This dropshipping system is a business that is currently in demand in the online business because besides that it makes it easy for resellers, with the dropshipping system, resellers don't need to get complaints from the orderer because the shipping process is very long (Sahil, 2019).

Buying and selling online using a personal online shop platform or on certain company marketplaces and with a dropshipping system or not necessarily becomes a new study in 
contemporary mu'alamah fiqh that needs to be discussed further about the law in online buying and selling activities. The concept of buying and selling the dropshipping model has been carried out by several researchers, including Ramadhani Khija, ludovick Uttoh (2015), Rusdiana \& Achmad Otong Bustomi (2015), Otong (2017), Hadi (2018), Nubahai (2019), and Pitriani \& Purnama (2020).

How is the law of online dropshipping buying and selling according to Islam the focus of discussion in this paper, the researcher deliberately presents the theme to be a material for study and discussion by academics, policy makers and the general public.

\section{LITERATURE REVIEW}

The theory, concept definitions, theoretical model frameworks can be seen in the following study, human interaction in society will create personal interests to meet their needs (Tijerina et al., 2020). From here will be born the rights and obligations that must be considered as a result of fulfilling the needs of human life. Every human being has his own rights and obligations (Brown, 2021). Therefore, the relationship between rights and obligations must be regulated in accordance with a clear law and order so as not to harm one another (Broderick, 2020). For example, every human being will definitely need property or other people's belongings. To meet these needs, the practice of bartering (exchanging goods) emerged, then direct buying and selling and now more advanced developments such as e-commerce. Practices like this need clear legal standards to protect the rights and obligations of each. From here, Muslim scholars undertake ijtihad to formulate clear and correct "rules of the game" according to Islamic Sharia known as figh mu'amalat(Ghulam, 2016).

Humans are also called economic beings, because by nature they will need goods and services throughout their life (Saefrudin, 2018). To fulfill this need, he will consider rationally based on customs, ethics and other social institutions as a basis for relations between humans in realizing their respective personal interests. In Islam, the fundamental philosophy of Islamic economics is monotheism (Hilmiyah et al., 2019). This concept of tawhid affirms that Allah is the one and only one, the creator of all creatures. Humans as creatures come from the same creation and have equal rights and obligations as caliphs on earth (Zaroni, 2012). Therefore, in Islamic economics there is no economic stratum, because the principle is equal distribution of economic resources for the benefit of human life and the universe.

Currently, economic transactions using dropshipping have become the norm in the community. Dropshipping is a transaction of buying and selling orders online, but the seller (dropship) never stores goods and takes care of shipping goods to consumers, but the owner of the goods (dropshipper) does it but on behalf of the online shop (dropship). At first glance, dropshipping is similar to bai' as-salam, especially parallel greetings (as-salam al-mawaji) in the banking world, because the number of parties involved in the contract is the same, namely customers, Islamic banks, and suppliers, as well as the type of contract used. is the order contract (Rusdiana \& Achmad Otong Bustomi, 2015).

In the concept of buying and selling according to Islamic economics, including dropshipping, it has been regulated in the Qur'an and hadith. Based on this research, the researcher can conclude that the dropshipping model of sale and purchase contract is allowed as long as it does not contain elements that can damage it such as usury, injustice, fraud, fraud, and the like and fulfills the principles and requirements in buying and selling according to Islam 
(Imaniyati et al., 2019). And in its application that the concept of dropshipping according to Islamic economics uses the agreement ba'i salam in accordance with the terms and conditions that have been applied in the ba'i salam (Andri Triyawan and Suthorik Eri Nugraha, 2018).

\section{METHOD}

The research method in this study has a type of qualitative research. With a literature or library approach. Sources of data in this study come from authoritative data and sources, such as books and journals that are still relevant to the mu'alamah dropshipping system from an Islamic economic perspective. Meanwhile, the data processing uses analytical content.

\section{RESULTS AND DISCUSSION}

\section{Islamic Economic View of the Law of Sale and Purchase}

Etymologically, al-bay'u البيع(buying and selling) is taking and giving something, and is a derivative of الباع(fathom) this is the habit of Arabs who hold out their fathoms when they enter into a sale and purchase contract to clap their hands as a sign that the contract has been done and mutually agreed or when they exchange goods and money (Kurniawaty \& Hendrawati, 2015).

Buying and selling is a matter of mu'amalat whose laws can vary, depending on the extent of the violation of sharia (Fitria, 2017a). Here are some buying and selling laws according to the conditions (Apipudin, 2018):

1) Buy and sell Halal

Originally, buying and selling is something that is permissible or permissible, as stated in the letter Al Baqarah verse 275 Allah SWT said,

"And Allah justifies buying and selling and forbids usury"<smiles>[AlH2][AsH2]=[AsH2]</smiles>

Buying and selling is lawful if both parties are willing to buy and sell, but this will be haram if certain things happen, for example if the buying and selling is prohibited by Rasulullah SAW or whose meaning includes those that are prohibited by him SAW. (Masrina, 2020).

2) Buying and selling Haram

Apart from buying and selling which is lawful, there is also buying and selling which is haram or prohibited, the scholars classify the prohibition of buying and selling by sorting the causes of the prohibition (Wulandari \& Zulqah, 2020). Among the reasons for the prohibition of a sale and purchase contract are:

a) Haram in connection with a contract, the prohibition of buying and selling related to a contract that is haram is divided into two, namely: Goods that violate Sharia, the prohibition is because the goods used as the object of the contract do not meet the terms and conditions in the contract, such as unclean objects or goods never existed, or the item is destructive and does not provide any benefit, or it may not be possible for the item to be handed over, A contract violates Sharia, for example buying and selling that contains elements of usury and gharar of all kinds. Trading is prohibited because there are elements of usury, including bai'ul 'inah, al-murabanah, al-mubaqalah, al-araya, al-'urbun, baiul akli' bil kali', and so on. Whereas trading is forbidden because of the gharar element between buying and selling animal fetuses that are still in its 
mother's stomach, buying and selling unripe fruit, bai'us-sinin, buying and selling fish in the water, buying and selling of slaves who run away from the master, buying and selling milk that is still in animal breasts, buying and selling wool that is still attached to goats, buying and selling oil in milk, and baiuts-tsuyya (Huda, 2019).

b) Haram in connection with things outside the contract, there are two kinds of trading which are forbidden because they are related to things outside the contract, namely: Absolute Dhararah, for example the sale and purchase of slaves that separate the mother and child, buying fruit juice that will be made into wine, buying and selling what is offered or bought by his siblings, Violating Religious Prohibitions, Among the examples of buying and selling is haram because it violates religion, for example, buying and selling carried out when the call to prayer is heard for Friday prayers, and buying and selling mushaf to unbelievers (Qardhawi, 2001).

A sale and purchase transaction requires the existence of a rukun as the enforcer, where without there, the sale and purchase becomes invalid. Generally, the scholars agree that there are at least three things that are harmonious in a sale, namely the existence of actors, namely sellers and buyers who meet the requirements, the existence of contracts or transactions, and the existence of goods or services being traded. (Khulwah, 2019). If one of the pillars above is not fulfilled then the contract is canceled and the sale and purchase is invalid.

In buying and selling, general requirements must be fulfilled which includes freedom from defects (disgrace) which includes jahalah fahisyah (ignorance), ikrah (coercion), gharar, and other destructive conditions. Jahalah fahisyah, namely obscurity which is fatal and will lead to disputes between the two transacting parties, both of which are in a strong position, the nature of this jahalah consists of the unclear object of the transaction, both in terms of type, type, and level (quality and quantity), unclear selling price of the object of the transaction, as well as unclear timing of payment in the context of buying and selling credit, the time must be clearly determined so that the contract will be free from the nature of the fasid. Gharar, there is uncertainty about the object of the transaction, both in terms of criteria or the existence of the object. So that the existence of the object is still in doubt by the buyer (Habiburrahman et al., 2020).

The transaction object must meet the following criteria (Yuna, 2014): a). The object of the transaction must exist when the contract is made, it is not valid to make a transaction on intangible goods, different from the sale and purchase of greetings, and istisna ', b). The object of the transaction is the property that is allowed by syara ', namely property that has a beneficial value for humans and allows it, c). The object of the transaction is in the possession of the seller, may not sell goods that are in the ownership of others or are in the wild, and d). The object of the transaction can be handed over when the contract is carried out or after the contract takes place.

The types of buying and selling based on the exchange are generally divided into four types, namely buying and selling greetings (orders) are buying and selling through orders, namely buying and selling by submitting advance advance then the goods are delivered later (Mujiatun, 2013); muqayadah sale (barter) is buying and selling by exchanging goods for goods (Tsabit, 2018); buying and selling mutlaq is buying and selling of goods with something that has been agreed as a means of exchange, such as money (Saidy, 2017); and buying and selling of an exchange tool with a medium of exchange (Yanggo, 2018). 


\section{What is Dropshipping?}

Dropshipping is a trading system where traders sell products but they are not owned and do not have inventory (stock of goods) (Mostarac et al., 2020; Pitriani \& Purnama, 2020). The seller only uses products from other places, for example goods belonging to suppliers, usually in the form of photographs, to be marketed to consumers, if they are sold, the seller buys goods from the supplier by asking the supplier to send goods on behalf of the seller (Kaluzhsky, 2013).

This system or method is suitable for those who are just starting a business but have limitations in terms of experience and minimal capital, because they do not need to use large capital and risks, because the dropshipping system is relatively very small (Witkowski et al., 2020).

Here is the dropshipping process (Winiarski \& Marcinkowski, 2020):

a.Make a list of products to be sold on the website, or through social media and chat applications.

b. When a product is sold, the seller submits consumer purchase data to (the goods owner or producer)

c. The buyer transfers money to the dropshipper according to the price of the goods plus shipping costs, then the dropshipper transfers money to the producer or owner of the goods minus the profits that have been taken.

d. If the payment goes well, the goods are sent directly by courier service and will arrive at the buyer in a few days (Wahhab \& Mujahidin, 2020).

Dropshippers never own goods directly and in buying and selling, sometimes they always see market trends and will look for suppliers of goods that are currently being hunted by the public (Israfilzade, 2017; Singh et al., 2018; Nurlaila, 2019; Amrita et al., 2020). Astuti's (2018) research results show that people's perceptions of online buying and selling contracts are quite good.

\section{Dropshipping is a Buying and Selling Solution: Islamic Economic Perspective}

Based on the description of the previous literature review, it is known that dropshipping can be a current buying and selling solution, and when viewed from an Islamic economic perspective, the following are solutions that can be offered:

The first solution, by using a Samsarah or brokerage contract, namely by establishing a cooperation agreement with the producer, and explaining the intention to become a broker or broker for the goods owned by the dropshipper. Furthermore, the benefits obtained through payment or fees are in accordance with mutual agreement and can be determined by the number of goods that have been sold, not based on the time of cooperation (Cahyo \& Nashuha, 2018).

The simsar contract is someone who sells other people's goods on the basis of the wages of the owner of the item with the effort he has done (Fauzia, 2016). People who become intermediaries in the trading system are called brokers, brokers and agents. In carrying out his role as a broker, he can act on behalf of his own company, or on behalf of the owner of his goods or commodities. Samsarah/simsar's work in the form of brokers, distributors, agents and so on in Islamic jurisprudence including the ijarah contract, which is a transaction utilizing the services of others in exchange for (Bahrudin, 2019). Al-ijarah comes from the word al-ajru which means to replace (Sartika \& Adinugraha, 2016). 
The basis for the simsar agreement was allowed to refer to a phenomenon during the time of the companions, Imam Bukhari said: "Ibn Sirin, Artha, Ibrahim, and Hasan saw that simsar was permissible". Ibn Abbas said in a hadith it stated the meaning: "From Ibn Abbas ra, in the case of simsar understanding, he said," It doesn't matter if someone says, "Sell this cloth at such a price, however much more (from the seller) is for you. " (HR Bukhari).

The mechanism is as follows:

1) The reseller as a broker or as an agent agrees with the owner of the goods, then determines the simsar contract agreement, for example the owner of the goods allows the reseller to sell his goods at a price of 10,000, if he can sell the goods, the owner of the goods will pay $10 \%$ of the price of the goods that have been sold or with an agreement that the owner of the goods allows the reseller to sell his goods for 10,000 and the reseller adds from that price, the additional of that price becomes the property of the reseller.

2) After establishing a partnership, the owner of the goods provides a photo or picture of the goods in his possession to the reseller, then the reseller markets the goods, either under his own company name or using the name of the company that owns the goods.

3) If the reseller finds a buyer, then the reseller asks the owner of the goods for help from the buyer through an expedition courier service.

Second solution, by using a sale and purchase contract and wakalah, which is to make a sale and purchase contract of an item but there are still some unfulfilled requirements and pillars, to perfect these terms and conditions, use the wakalah contract (Madinah et al., 2019). The terms and conditions that are not fulfilled in the dropshipping system are:

1) The object of buying and selling is when the contract is made

2) The object of sale and purchase must be proprietary. As previously explained, the criteria for the perpetrator or contract are that he must meet the criteria for expertyah, territory and fudhuli, fudhuli, namely people who make transactions on cases or other people's rights without having territory (power in ownership of goods) over other people's cases or rights. According to the Hanafiyah and Malikiyah schools of thought, fudhuli is legal, but with the permission of the owner of the goods and the person doing it has expertise in its operation. The solution is that the reseller can become a representative of the owner of the goods to sell the goods, thus the reseller will benefit by getting the ujroh (wages) of what is done from the owner of the goods (Fikri, 2019). Thus the mechanism in this second solution is:

a) The reseller agrees to make a contract with the owner of the goods as a representative in selling the goods.

b) The owner of the goods provides a detailed and clear photo and classification of the item to the representative.

c) The representative then markets the goods according to the information obtained from the owner of the goods.

d) When the representative or reseller finds the buyer, then after processing the payment, the representative asks the owner of the goods to send it to the buyer, if there is a discrepancy in the goods, the buyer has the right khiyar ru'yah (right to see the commodity). Khiyar ru'yah is the right to vote for the buyer to declare valid 
or cancel the sale and purchase he has made of an object that he has not seen when the contract took place.

The third solution is to use the salam contract system (bai 'salam), namely buying and selling where the price payment is submitted first, while the goods are delivered later at a predetermined time (Saprida, 2018).

The pillars that must be fulfilled in the greeting are there is the seller and the buyer, there are goods and money, and there is shighat (Tufik, 2020). Whereas the terms of the Salam are that payment is made in advance, the goods become a debt to the seller, the goods can be given according to the promised time, the size of the goods should be clear, whether the measurement, the scale, the size or the number, according to the custom of how to sell the goods, and it is known and mentioned the nature of the goods (Akbar, 2018).

With these characteristics and clear prices, the desire of people to buy the goods is clear and with these clear characteristics and characteristics, it does not cause a dispute at the end of the transaction (Abdullah \& Asniati, 2021).

Thus the dropshipping system mechanism using the greeting contract is as follows: Resellers market photos or images and determine the selling price and the benefits; when a buyer is interested in the item, the buyer orders the item from the reseller. The buyer pays in advance in cash for the goods ordered, then the reseller looks for the goods, when the reseller gets the goods and according to the order, the reseller buys the goods, as well as asks the seller for help to send them to the buyer; and in this case, if the goods delivered do not match the order, the buyer can cancel the transaction, so the reseller is responsible for it.

\section{CONCLUSION}

Based on the description above, we can conclude the following: allowed transactions that continue to develop in economic progress as long as they do not violate and do not contradict Islamic principles, dropshipping transactions which have now become a custom in society are allowed as long as the perpetrator understands the procedures for making transactions, because the system is vulnerable and leads to the cancellation of a contract, namely selling goods that do not belong to him, and the development of technology greatly influences the development of legal edicts that urge to be issued. However, on many sides, with the legal norms that have been summarized by previous scholars by looking at the equality of legal 'illat, it can be found that fast and precise legal answers can be found to determine the law in every legal event for which there is no clear legal provision in al-Qur'an and as-Sunnah.

\section{REFERENCES}

Abdullah, M. W., \& Asniati. (2021). Islamic Maqashid Approach On Dropshipping Practices. International Journal Research Granthaalayah, 9(1). https://doi.org/10.29121/granthaalayah.v9.i1.2021.2892

Aco, A., \& Endang, A. H. (2017). Analisis Bisnis E-Commerce pada Mahasiswa Universitas Islam Negeri Alauddin Makassar. Jurnal Teknik Informatika, 2.

Akbar, A. (2018). Analisis Transaksi Akad Salam Dalam Jual Beli Online. EKSISBANK: Ekonomi Syariah Dan Bisnis Perbankan, 2(2). https://doi.org/10.37726/ee.v2i2.47 
Amrita, G. A. D. D., Mahendrawati, N. L. M., \& Ujianti, N. M. P. (2020). Perlindungan Hukum bagi Konsumen dalam Transaksi Jual Beli melalui Media Elektronik dengan Sistem "Dropship". Jurnal Konstruksi Hukum, 1(1). https:// doi.org/10.22225/jkh.1.1.2146.135-139

Andri Triyawan dan Suthorik Eri Nugraha. (2018). Sistem Dropshipping Menurut Ekonomi Islam ,. Human Falah, 5(2), 230.

Apipudin, A. (2018). Konsep Jual Beli Dalam Islam (Analisis Pemikiran Abdu al-Rahman alJaziri dalam Kitab al-Fiqh 'Ala alMadahib al-Arba'ah). Islaminomics: Journal of Islamic Economics, Business and Finance, 5(2). https://doi.org/10.47903/ji.v5i2.33

Astuti, D. (2018). Persepsi Masyarakat Terhadap Akad Jual Beli Online Perspektif Ekonomi Syariah. Syarikat: Jurnal Rumpun Ekonomi Syariah, 1(1). https://doi.org/10.25299/syarikat.2018.vol1(1).2625

Bahrudin, M. (2019). Ilmu Ushul Fiqh. In Journal of Chemical Information and Modeling (Vol. 53, Issue 9).

Broderick, A. (2020). Of rights and obligations: the birth of accessibility. International Journal of Human Rights, 24(4). https://doi.org/10.1080/13642987.2019.1634556

Brown, R. D. (2021). Property ownership and the legal personhood of artificial intelligence. Information and Communications Technology Law, 30(2). https://doi.org/10.1080/13600834.2020.1861714

Cahyo, E. N., \& Nashuha, R. H. (2018). Dropship Selling Mechanism on The View of Islamic Economics Law. Al-Mu'amalat: Journal of Islamic Economic Law, 1(1).

Damayanti, T., \& Gemiharto, I. (2019). Kajian Dampak Negatif Aplikasi Berbagi Video Bagi Anak-Anak Di Bawah Umur Di Indonesia. Communication, 10(1). https://doi.org/10.36080/comm.v10i1.809

Fauzia, I. Y. (2016). Akad Wakâlah dan Samsarah sebagai Solusi atas Klaim Keharaman Dropship dalam Jual Beli Online. ISLAMICA: Jurnal Studi Keislaman, 9(2). https://doi.org/10.15642/islamica.2015.9.2.323-343

Febriani, N. S., Dewi, W. W. A., \& ... (2020). Perilaku Konsumen terhadap Kualitas e-Service pada e-Commerce. Ultimacomm: Jurnal Ilmu ....

Fikri, M. K. (2019). Perspektif Etika Bisnis Islam Pada Sistem Konsinyasi Dalam Strategi Reseller. BISNIS: Jurnal Bisnis Dan Manajemen Islam, 7(2). https://doi.org/10.21043/bisnis.v7i2.5731

Fitria, T. N. (2017a). Bisnis Jual Beli Online (Online Shop) Dalam Hukum Islam Dan Hukum Negara. Jurnal Ilmiah Ekonomi Islam, 3(01). https:/ / doi.org/10.29040/jiei.v3i01.99

Fitria, T. N. (2017b). Bisnis Jual Beli Online (Online Shop) Dalam Hukum Islam Dan Hukum Negara. Jurnal Imiah Ekonomi Islam, Vol. 03.

Ghulam, Z. (2016). Relasi Fiqh Muamalat Dengan Ekonomi Islam. Iqtishoduna, 8(2).

Habiburrahman, habiburrahman, Arahman, R., \& Lamusiah, S. (2020). Transaksi yang Mengandung Unsur Riba, Maysir, dan Gharar dalam Kajian Tindak Tutur. Jurnal Ilmiah Telaah, 5(2).

Hadi, R. (2018). Analisis Praktek Jual Beli Dropshipping Dalam Perpektif Ekonomi Islam. Jurnal Informasi Kimia Dan Pemodelan, 53(9).

Hilmiyah, N., Possumah, B. T., \& Mohd Shafiai, M. H. (2019). Tawhid and Shariah Economics: Positioning Tauhid as Philosophical Foundation of Shariah Economics. AL-FALAH: Journal of Islamic Economics, 4(2). https://doi.org/10.29240/alfalah.v4i2.890 
Huda, R. (2019). Akad Construction On Credit Card Products (Analysis Of Sharia Economic Laws). Syariab: Jurnal Hukum Dan Pemikiran, 19(1). https://doi.org/10.18592/sjhp.v19i1.2041

Imaniyati, N. S., Nurhasanah, N., \& Tohir, T. (2019). The concept of contract in financial technology era connected with sharia principles. Opcion, 35(SpecialEdition24).

Imanudi, R. (2019). Jual Beli Online Menggunakan Sistem Dropshipping Menurut Perspektif Hukum Islam. Indonesian Journal of Strategic Management, 2(1). https://doi.org/10.25134/ijsm.v2i1.1857

Israfilzade, K. (2017). Advantages and Disadvantages of Dropshipping. Young Scientist, 7(47).

Kaluzhsky, M. (2013). Marketing features of dropshipping in system of e-commerce. Practical Marketing, 6 (196).

Khulwah, J. (2019). Jual Beli Dropship Dalam Prespektif Hukum Islam. Al-Mashlahah Jurnal Hukum Islam Dan Pranata Sosial, 7(01). https://doi.org/10.30868/am.v7i01.548

Kurniawan, Y., \& Kosasih, W. (2020). Relation Commitment Pada E-Marketplace. Strategic Management $O f \ldots$.

Kurniawaty, Y., \& Hendrawati, H. (2015). Jual Beli Dalam Perspektif Hukum Islam. Jurnal Informasi Dan Pengembangan Iptek, 11(1).

Madinah, S. H., Sari, P. K., \& Rofiqoh, I. (2019). Analisis Akad Wakalah Bil Ujrah pada Jasa Titip Beli Online dalam Prespektif Kaidah Fikih Ekonomi (Studi Kasus pada Akun Instagram @jastiperopa777). El-Qist: Journal of Islamic Economics and Business (JIEB), 9(2). https://doi.org/10.15642/elqist.2019.9.2.196-214

Maryati, W., \& Masriani, I. (2019). PELUANG BISNIS DI ERA DIGITAL BAGI GENERASI MUDA DALAM BERWIRAUSAHA: STRATEGI MENGUATKAN PEREKONOMIAN. Jurnal MEBIS (Manajemen Dan Bisnis), 4(2). https://doi.org/10.33005/mebis.v4i2.62

Masrina, M. (2020). Analisis Dalil-Dalil Hukum yang Digunakan dalam Fatwa Dewan Syariah Nasional Nomor 40/DSN-MUI/X/2003 tentang Pasar Modal Syariah. Jurnal Hukum Ekonomi Syariah, 1. https://doi.org/10.30595/jhes.v0i1.8929

Mostarac, K., Kavran, Z., \& Pišković, J. L. (2020). Dropshipping distribution model in supply chain management. Annals of $D A A A M$ and Proceedings of the International DAAAM Symposium, 31(1). https://doi.org/10.2507/31st.daaam.proceedings.019

Mujiatun, S. (2013). Jual Beli Dalam Perspektif Islam : Salam Dan Istisna'. Jurnal Riset Akuntansi Dan Bisnis, 13(September).

Nubahai, L. (2019). Konsep Jual Beli Model Dropshipping Prespektif Ekonomi Islam. MISYKAT: Jurnal Ilmu-Ilmu Al-Quran, Hadist, Syariah Dan Tarbiyah, 4(1). https://doi.org/10.33511/misykat.v4i1.74

Nurlaila, A. R. (2019). Marketing Management System of Dropshipping Islamic Economic Perspective (Case Study at Purwokerto Online We Skincare Store). International Conference of Moslem Society, 3. https://doi.org/10.24090/icms.2019.2510

Otong, A. (2017). Dropshipping transaction in shariah economic perspective. Munich Personal RePEc Archive, 76302.

Pitriani, E., \& Purnama, D. (2020). Dropshipping Dalam Perspektif Konsep Jual Beli Islam. Jurnal Ekonomi Dan Perbankan Syariah, 3(2). https://doi.org/10.46899/jeps.v3i2.162

Putra, M. D. (2019). Jual Beli On-Line Berbasis Media Sosial Dalam Perspektif Ekonomi Islam. 
ILTIZAM Journal of Shariah Economic Research, 3(1). https://doi.org/10.30631/iltizam.v3i1.288

Qardhawi, Y. Al. (2001). Halal dan Haram dalam Islam. Pustaka Nasional Pte Ltd.

Rahmayanti, R., Padmakusumah, R. R., Susanti, N., \& Susanto, R. (2020). The maintaining of trust of online business trading from islamic perspective. International Journal of Psychosocial Rehabilitation, 24(2). https://doi.org/10.37200/IJPR/V24I2/PR200610

Ramadhani Khija, ludovick Uttoh, M. K. T. (2015). Jual Beli Online dengan Menggunakan Dropshipping Menurut Sudut Pandang Akad Jual Beli Islam. Ekp, 13(3).

Rismana, H. (2018). Analisis Faktor-Faktor Yang Mempengaruhi Preferensi Pembayaran Pelanggan Pada E-Marketplace. Tugas Akhir.

Rusdiana, \& Achmad Otong Bustomi. (2015). Transaksi Dropshipping Perspektif Ekonomi Syari'Ah. Al-Mustashfa, 3(1).

Saefrudin. (2018). Pengorganisasian Dalam Manajemen. Dirasah : Jurnal Studi Imu Dan Manajemen Pendidikan Islam, 1(1). https://doi.org/10.29062/dirasah.v1i1.9

Sahil, I. (2019). Dropshipping Dalam Perspektif Ekonomi Islam. Syaikhuna: Jurnal Pendidikan Dan Pranata Islam, 10(1). https://doi.org/10.36835/syaikhuna.v10i1.3472

Saidy, E. N. (2017). UANG DALAM TINJAUAN EKONOMI ISLAM. Jurnal LAA MAISYIR, Vol 6(No.2).

Saprida, S. (2018). Akad Salam Dalam Transaksi Jual Beli. Mizan: Journal of Islamic Law, 4(1). https://doi.org/10.32507/mizan.v4i1.177

Sartika, M., \& Adinugraha, H. H. (2016). Implementasi Ijārah Dan Imbt Pada Bank Bri Syariah Cabang Yogyakarta. Economica: Jurnal Ekonomi Islam, 7(1), 97. https://doi.org/10.21580/economica.2016.7.1.1034

Singh, G., Kaur, H., \& Singh, A. (2018). Dropshipping in e-commerce: A perspective. ACM International Conference Proceeding Series. https:// doi.org/10.1145/3271972.3271993

Tijerina, J. D., Morrison, S. D., Nolan, I. T., Vail, D. G., Lee, G. K., \& Nazerali, R. (2020). Analysis and interpretation of google trends data on public interest in cosmetic body procedures. Aesthetic Surgery Journal, 40(1). https://doi.org/10.1093/asj/sjz051

Tsabit, A. M. (2018). Etika Pertukaran dalam Islam Menurut Imam Al-Ghazali. JPIK (Jurnal Pemikiran Dan Ilmu Keislaman), 1(1).

Tufik, T. (2020). Akad As-Salam dalam Sistem Jual Beli Online. Jurnal Agbinya Stiesnu Bengkulu, $3(1)$.

Wahhab, M. A., \& Mujahidin, M. (2020). Dropship dalam perpektif ekonomi Islam. Al-Kharaj: Journal of Islamic Economic and Business, 1(2). https://doi.org/10.24256/kharaj.v1i2.1060

Wibowo, E. A. (2016). Pemanfaatan Teknologi E-Commerce Dalam Proses Bisnis. Equilibiria, 1(1).

Winiarski, J., \& Marcinkowski, B. (2020). e-Commerce Websites and the Phenomenon of Dropshipping: Evaluation Criteria and Model. Lecture Notes in Business Information Processing, 402. https://doi.org/10.1007/978-3-030-63396-7_19

Witkowski, K., Koralewska, M., \& Huk, K. (2020). Logistics Models in E-Commerce. Research Papers Faculty of Materials Science and Technology Slovak University of Technology, 28(46). https://doi.org/10.2478/rput-2020-0012

Wulandari, C., \& Zulqah, K. A. (2020). Tinjauan Islam terhadap Mekanisme Pasar dan 
Penanganan Distorsinya. Journal of Islamic Economics and Finance Studies, 1(1). https://doi.org/10.47700/jiefes.v1i1.1923

Yanggo, H. T. (2018). Moderasi Islam dalam Syariah. Al-Mizan: Jurnal Hukum Dan Ekonomi Islam, 2(2).

Yuna, N. M. (2014). Analisis Ekonomi Islam Terhadap Jual Beli Padi Sawah Di Kecamatan Manggeng Aceh Selatan. Share: Jumal Ekonomi Dan Keuangan Islam, 3(2). https://doi.org/10.22373/share.v3i2.1343

Zaroni, A. N. (2012). Landasan Filosofis Perilaku Konsumen Dalam Perspektif Ekonomi Islam Dan Konvensional. Marabib, 10(1). 